\title{
APLIKASI JUAL BELI SBSN (SUKUK NEGARA) SECARA LELANG DI INDONESIA
}

\author{
Burhanuddin Susamto \\ Fakultas Syari'ah Universitas Islam Maulana Malik Ibrahim Malang \\ E-Mail: Burhanuddin_islam@yahoo.com, \\ HP. 085228143509
}

\begin{abstract}
In financial empowerment, the government needs to improve efficiency in the management of state assets through efforts to diversify sources of financing the national budget. Conventional financing instruments issued by governments are ever Government Securities (SUN). Such instruments are operated based on usury system (riba) that becomes its own expense for the state budget from year to year. Not to mention it is evaluated in terms of the transcendental, SUN based on usury means has violated religious teachings. Therefore, as an alternative effort, the government has elicits other financing instruments, such as through an auction sale (penjualan lelang) of the SBSN (Sovereign Sukuk) which has been published.
\end{abstract}

Keywords: Riba, Penjualan, Lelang, SBSN, Sukuk

Untuk pengelolaan keuangan negara melalui upaya penguatan Anggaran Pendapatan dan Belanja Negara (APBN) sebagai fundamental pembangunan perekonomian nasional secara berkesinambungan, maka diperlukan berbagai instrumen keuangan yang mampu memobilisasi dana publik secara luas sebagai wujud partisipasi. Meskipun potensi sumber pembiayaan pembangunan nasional yang menggunakan instrumen keuangan berbasis syariah memiliki peluang besar, namun belum dimanfaatkan secara optimal. Penerapan sistem keuangan berbasis syariah perlu ditumbuh kembangkan melalui pembentukan instrumen pembiayaan yang mengedepankan pada pertumbuhan ekonomi sektor riil. Instrumen keuangan berdasarkan prinsip syariah mempunyai karakteristik yang berbeda dengan instrumen keuangan konvensional, sehingga perlu pengelolaan khusus, baik yang menyangkut motode maupun perangkat hukum yang diperlukan .

Konsep keuangan berbasis syariah Islam (Islamic Finance) sekarang ini, telah mengalami pertumbuhan secara pesat, diterima secara universal dan 
diadopsi tidak hanya oleh negara-negara Islam melainkan juga oleh berbagai negara lain di belahan dunia. Fenomena ini ditandai dengan didirikannya lembaga-lembaga keuangan, untuk menerbitkan berbagai instrumen pembiayaan berbasis syariah. Disamping itu, pada tingkat global juga telah dibentuk lembaga internasional untuk merumuskan infrastruktur sistem ekonomi Islam, lengkap dengan standar instrumen keuangannya. Salah satu bentuk instrumen keuangan syariah yang telah banyak diterbitkan baik oleh korporasi maupun negara adalah instrumen sukuk. Istilah sukuk merupakan nama lain dari obligasi syariah yang menjadikan akad-akad muamalah sebagai dasar transaksi (underlying transaction).

Melihat pesatnya perkembangan sukuk di negara-negara lain, serta pengalaman yang terjadi selama ini, terutama dari segi manfaat yang ditimbulkannya, pemerintah merasa berkepentingan untuk mengeluarkan regulasi yang dapat mendukung perkembangan sukuk di dalam negeri. Sebagai tindak lanjut, penerapan sukuk diwujudkan kedalam bentuk penerbitan Surat Berharga Syariah Negara (SBSN) yang dimaksudkan untuk mencari alternatif sumber pembiayaan negara.

Berdasarkan Peraturan Perundang-undangan No.19 Tahun 2008, telah dinyatakan bahwa:

"Surat Berharga Syariah Negara (SBSN) atau sukuk negara (sovereign sukuk) adalah: Surat berharga negara yang diterbitkan berdasarkan prinsip syariah, sebagai bukti atas bagian penyertaan terhadap Aset SBSN, baik dalam mata uang rupiah maupun valuta asing (Pasal 1 angka 1)".

Kata sukuk (صكوث) bentuk jamak dari sakk (صك) merupakan istilah Arab yang dapat diartikan sertifikat. Sukuk ini bukan merupakan istilah yang baru dalam sejarah Islam. Istilah tersebut sudah dikenal sejak abad pertengahan, dimana umat Islam menggunakannya dalam konteks perdagangan internasional. Sukuk dipergunakan oleh para pedagang pada masa itu sebagai dokumen yang menunjukkan kewajiban finansial yang timbul dari usaha perdagangan dan aktivitas komersial lainnya. Namun sejumlah penulis Barat yang memiliki konsen terhadap sejarah Islam dan bangsa Arab menyatakan, bahwa dari kata sakk inilah yang kemudian menjadi akar kata "cheque" dalam bahasa latin, 
sebagai suatu istilah yang lazim dipergunakan dalam transaksi dunia perbankan kontemporer (Huda dan Nasution, 2008).

Sedangkan berdasarkan Fatwa No: 69/DSN-MUI/VI/2008 dijelaskan bahwa, yang dimaksud Surat Berharga Syariah Negara atau Sukuk Negara adalah surat berharga negara yang diterbitkan berdasarkan prinsip syari'ah, sebagai bukti atas bagian (حصة) kepemilikan asset SBSN, baik dalam mata uang rupiah maupun valuta asing. Menurut Sharia Standard No.17 tentang Investment, pengertian sukuk adalah:

"Investment Sukuk are certificates of equal value representing undivided shares in ownership of tangible assets, usufruct and services or (in the ownership of) the assets or particular projects or special investment activity, however, this is true after receipt of the value of the sukuk, the closing of subcription and the employment of funds received for the purpose for which the sukuk were issued."

Sedangkan menurut Accounting and Auditing Organization for Islamic Financial Institutions (AAOIFI), yang dimaksud dengan sukuk adalah: "Certificates of equal value representing undivided shares in ownership of tangible assets, usufruct and services or (in the ownership of) the assets of particular projects or special investment activity."

Dalam peraturan No. IX.A.14 tentang penerbitan efek syariah, istilah "sukuk" diartikan sebagai efek syariah berupa sertifikat atau bukti kepemilikan yang bernilai sama dan mewakili bagian penyertaan yang tidak terpisahkan atau tidak terbagi atas: (1) kepemilikan aset berwujud tertentu; (2) nilai manfaat dan jasa atas aset proyek tertentu atau aktivitas investasi tertentu; atau (3) kepemilikan atas aset proyek tertentu atau aktivitas investasi tertentu. (Lihat Pasal 1 huruf d Keputusan Ketua Bapepam-LK No: KEP-130/BL/2006 tentang Penerbitan Efek Syari'ah).

Lelang adalah salah satu jenis jual beli di mana pembeli menawarkan barang di tengah keramaian lalu para pembeli saling menawar dengan harga lebih tinggi sampai pada batas harga tertinggi dari salah satu pembeli, lalu terjadi akad dan pembeli tersebut mengambil barang dari penjual (Al-Muslih\& Ash-Shawi, 2004:110). Lelang SBSN adalah penjualan SBSN yang dilakukan 
melalui agen lelang yang mana investor menyampaikan penawaran pembelian baik secara kompetitif maupun non kompetitif melalui peserta lelang.

Dalam kitab-kitab fiqih atau hadits, jual beli lelang biasanya disebut dengan istilah bai' al-muzayadah (Al-Jaziri, t.t: II/275). Jual beli lelang (bai' almuzayadah) dalam Islam hukumnya adalah boleh (mubah). Dalil bolehnya lelang adalah as-Sunnah. Imam Bukhari telah membuat bab dengan judul Bab Bai' AlMuzaayadah dan di dalamnya terdapat hadits Anas bin Malik RA yang juga diriwayatkan oleh Imam Ahmad (Musnad, III/100 \& 114), Abu Dawud, no. 1641; An-Nasa i, VII/259, At-Tirmidzi, hadits no. 1218 (Lihat Imam Ash-Shan'ani, Subulus Salam, Juz III/23; Abdullah al-Mushlih \& Shalah ash-Shawi, ibid., hal. 111).

Seorang laki-laki dari kaum Ansar datang menemui Nabi untuk meminta (sesuatu yang ia perlukan). Nabi bertanya: “Apakah di rumahmu ada sesuatu?" Ia menjawab: "Ada, selembar hils (alas yang biasanya digelarkan di rumah) yang sebagiannya kami pakai dan sebagiannya kami gelar, dan sebuah qa'b (qadah, gelas) yang biasa kami gunakan untuk minum air." Nabi bersabda: "Coba anda serahkan kepada saya kedua barang tersebut." Laki-laki itu kemudian mengambil dan menyerahkan keduanya kepada Nabi. Nabi pun menerimanya.

Kemudian Nabi menawarkan: "Siapakah yang mau membeli dua barang ini?" Seseorang berkata: "Saya siap membeli keduanya dengan harga 1 (satu) dirham." Nabi menawarkan lagi, hingga dua atau tiga kali: "Man yazid 'ala dirhamin (siapakah yang mau menambahkan pada satu dirham)?" Seseorang menjawab: "Saya mau membeli keduanya dengan harga dua dirham." Nabi pun menyerahkan kedua benda itu kepadanya dan menerima dua dirham, lalu menyerahkan uang (dua dirham) tadi kepada orang Ansar tersebut, dan bersabda: "Belilah makanan dengan satu dirham, lalu berikan kepada keluargamu; satu dirham lagi kamu belikan kapak dan nanti serahkan kepadaku." Orang tersebut kemudian menyerahkan kapak kepada Nabi; Nabi menerimanya lalu Nabi memasangkan kayu (memberinya gagang). Nabi bersabda: "Pergilah mencari kayu bakar (hathab), dan juallah! Saya tidak mau melihatmu selama 15 hari."

Kemudian orang itu pergi mencari kayu bakar dan menjualnya. Setelah itu mendapat uang 10 dirham, orang tersebut datang lagi; lalu uang tersebut ia belikan makanan dan pakaian. Rasul bersabda: "Apa yang kamu lakukan itu lebih baik bagi kamu daripada kamu meminta-minta yang kelak pada hari kiamat akan menjadi nuktah (noda) di wajahmu...." (HR. Abu Dawud). 
Rasulullah SAW menjual sehelai hils (alas yang biasanya digelarkan di rumah) dan sebuah qadah (gelas). Beliau menawarkan: "Sipakah yang mau membeli hils dan qadah ini?" Seseorang berkata: "Saya siap membeli keduanya dengan harga 1 (satu) dirham." Nabi menawarkan lagi, hingga dua kali: "Man yazid 'ala dirhamin (siapakah yang mau menambahkan pada satu dirham)?" Lalu seseorang menyerahkan dua dirham kepada Rasulullah." Beliau pun menjual kedua benda itu kepadanya (Hadits Nabi riwayat Tirmizi dari Anas bin Malik).

Dari dalil-dalil tersebut telah jelas, bahwa hukum asal jual beli lelang adalah boleh (mubah). Namun yang menjadi pertanyaan, bagaimana ketentuan lelang apabila dikaitkan dengan penjualan SBSN? Untuk menjawab pertanyaan tersebut, perhatikan penjelasan berikut ini.

\section{Penjualan SBSN Secara Lelang}

Lelang SBSN merupakan bentuk penjualan SBSN yang dilakukan melalui agen lelang yang mana investor menyampaikan penawaran pembelian baik secara kompetitif maupun non kompetitif melalui peserta lelang. Untuk menjamin terpenuhinya aspek syariah dalam penerbitan SBSN, maka pelaksanaan lelang termasuk penentuan harga SBSN harus sesuai dengan prinsip syariah. Ketentuan lebih lanjut mengenai Penerbitan dan Penjualan Surat Berharga Syariah Negara (SBSN) di Pasar Perdana Dalam Negeri dengan cara Lelang termuat pada Peraturan Menteri Keuangan No. 11 /PMK. 08/2009. Dengan tetap mengacu pada peraturan ini, penulis dapat menjelaskan secara lebih lanjut sebagai berikut:

Penerbitan SBSN dapat dilaksanakan secara langsung oleh Pemerintah atau melalui Perusahaan Penerbit. Apabila penerbitan SBSN dilakukan secara langsung oleh Pemerintah, maka kegiatan persiapan dan pelaksanaan penerbitan SBSN dilaksanakan oleh satuan kerja di lingkungan Departemen Keuangan yang tugas pokok dan fungsinya menyelenggarakan pengelolaan SBSN. Sedangkan apabila penerbitan SBSN dilakukan secara tidak langsung, maka kegiatan persiapan dan pelaksanaan penerbitan SBSN dilaksanakan oleh Perusahaan Penerbit SBSN dengan dibantu oleh satuan kerja di lingkungan Departemen Keuangan yang tugas pokok dan fungsinya menyelenggarakan pengelolaan SBSN. 
Untuk persiapan penerbitan, menteri dapat menunjuk Bank Indonesia sebagai agen lelang guna melaksanakan lelang SBSN. Dalam hal Bank Indonesia bertindak sebagai agen lelang SBSN, ketentuan lebih lanjut mengenai teknis pelaksanaan lelang SBSN mengikuti ketentuan peraturan yang dikeluarkan Bank Indonesia. Agen lelang sebagaimana dimaksud mempunyai tugas sebagai yaitu: (1) Mengumumkan rencana Lelang SBSN yang memuat paling kurang nama Peserta Lelang SBSN, waktu pelaksanaan lelang SBSN, jumlah indikatif SBSN yang ditawarkan, jangka waktu SBSN, tanggal penerbitan, tanggal Setelmen, tanggal jatuh tempo, jenis mata uang dan waktu pengumuman hasil Lelang SBSN kepada Peserta Lelang melalui sistem Lelang SBSN; (2) Melaksanakan Lelang SBSN; (3) Menyampaikan data penawaran Lelang SBSN kepada Menteri c.q. Direktur Jenderal Pengelolaan Utang; dan (3) Mengumumkan hasil ketetapan Lelang SBSN kepada Peserta Lelang melalui sistem Lelang (Lihat: Pasal 3 ayat 2).

Setiap pihak dapat menyampaikan penawaran pembelian dalam Lelang SBSN. Bank Indonesia dapat membeli SBSN di pasar perdana hanya SBSN jangka pendek untuk dan atas nama dirinya sendiri. Sedangkan Lembaga Penjamin Simpanan (LPS) dapat membeli SBSN di pasar perdana berupa SBSN jangka pendek maupun jangka panjang untuk dan atas nama dirinya sendiri. Pembelian SBSN secara lelang di pasar perdana oleh pihak selain Bank Indonesia dan LPS dilakukan melalui peserta lelang. Pengertian peserta lelang adalah bank, perusahaan efek, dan anggota dealer utama sebagaimana dimaksud dalam peraturan menteri keuangan tentang sistem dealer utama, yang ditunjuk menteri sebagai peserta lelang SBSN di pasar perdana dalam negeri.

Bagi bank, perusahaan efek, dan anggota dealer utama dapat mengajukan permohonan sebagai peserta lelang SBSN kepada Menteri c.q. Direktur Jenderal Pengelolaan Utang untuk mendapatkan persetujuan serta menyerahkan surat pernyataan kesediaan untuk mematuhi ketentuan sebagai peserta lelang. Khusus untuk bank selain anggota dealer utama yang akan menjadi peserta lelang SBSN harus memenuhi persyaratan yaitu: (1) Memiliki izin usaha yang masih berlaku dari otoritas yang berwenang; (2) Memenuhi persyaratan Kewajiban Penyediaan Modal Minimum (KPMM) berdasarkan Peraturan Bank Indonesia; dan (3) Menjadi peserta Bank Indonesia Scripless Securities Settlement System (BI-SSSS) 
(Pasal 8). Sedangkan bagi Bank selain anggota Dealer Utama yang akan menjadi Peserta Lelang SBSN harus memenuhi persyaratan diantaranya: (1) Memiliki izin usaha yang masih berlaku dari otoritas di bidang pasar modal; (2) Memenuhi Modal Kerja Bersih Disesuaikan (MKBD) minimal rata-rata harian selama satu bulan terakhir sebesar Rp. 200.000.000.000,00 (dua ratus miliar rupiah); dan (3) Menjadi peserta Bank Indonesia Scripless Securities Settlement System (BI-SSSS) (Pasal 9).

Penawaran pembelian dalam lelang SBSN dapat dilakukan dengan cara kompetitif dan/atau nonkompetitif. Karena itu untuk pelaksanaan lelang SBSN, sebelumnya pemerintah dapat menetapkan ketentuan tentang: jenis akad, tanggal jatuh tempo, tanggal lelang, target indikatif, metode penetapan harga SBSN, persentase alokasi bagi penawaran pembelian non kompetitif untuk SBSN yang akan ditawarkan, serta Barang Milik Negara yang akan digunakan sebagai aset SBSN atau objek pembiayaan SBSN. Penetapan hal-hal sebagaimana dimaksud dilakukan oleh Direktur Jenderal Pengelolaan Utang untuk dan atas nama menteri.

Penawaran pembelian kompetitif (Competitive Bidding) adalah pengajuan penawaran pembelian SBSN dengan mencantumkan: (a) Volume dan tingkat imbal hasil yang diinginkan penawar, dalam hal lelang SBSN dengan pembayaran imbalan tetap (fixed coupon) atau pembayaran imbalan secara diskonto; atau (b) Volume dan harga yang diinginkan penawar, dalam hal lelang SBSN dengan imbalan mengambang (floating coupon).

Penetapan harga SBSN bagi pemenang lelang SBSN dengan penawaran pembelian kompetitif dapat dilakukan dengan metode harga beragam atau dengan metode harga seragam. Harga beragam (Multiple Price) adalah harga yang dibayarkan oleh masing-masing pemenang lelang SBSN sesuai dengan harga penawaran yang diajukannya. Sedangkan harga seragam (Uniform Price) adalah tingkat harga yang sama yang dibayarkan oleh seluruh pemenang lelang SBSN.

Penawaran pembelian non kompetitif (Non Competitive Bidding) adalah pengajuan penawaran pembelian dengan mencantumkan: (a) Volume tanpa tingkat imbal hasil yang diinginkan penawar, dalam hal lelang SBSN dengan pembayaran imbalan tetap atau pembayaran imbalan secara diskonto; atau (b) 
Volume tanpa harga yang diinginkan penawar, dalam hal lelang SBSN dengan pembayaran imbalan mengambang.

Penetapan harga SBSN bagi pemenang lelang SBSN dengan penawaran pembelian non kompetitif dilakukan berdasarkan harga rata-rata tertimbang hasil lelang penawaran pembelian kompetitif. Maksud pengertian harga rata-rata tertimbang (Weight Average Price) adalah harga yang dihitung dari hasil bagi antara jumlah dari perkalian masing-masing volume SBSN dengan harga yang dimenangkan dan total volume SBSN yang terjual.

Bank Indonesia hanya dapat menyampaikan penawaran pembelian SBSN jangka pendek dengan cara non kompetitif. Begitu pula dengan Lembaga Penjamin Simpanan (LPS) yang hanya dapat menyampaikan penawaran pembelian SBSN dengan cara nonkompetitif. Sedangkan bagi peserta lelang yang menyampaikan penawaran pembelian SBSN jangka pendek untuk dan atas nama pihak selain Bank Indonesia dan LPS, hanya dapat melakukan penawaran pembelian dengan cara kompetitif. Kemudian bagi Peserta lelang yang menyampaikan penawaran pembelian SBSN jangka panjang untuk dan atas nama pihak selain Bank Indonesia dan LPS, maka dapat melakukan penawaran pembelian dengan cara kompetitif dan/ atau dengan cara non kompetitif.

Hasil lelang yang meliputi nilai nominal SBSN yang dimenangkan serta tingkat imbalan dan/ atau diskonto, termasuk jenis dan nilai Aset SBSN, pada tanggal pelaksanaan lelang SBSN ditetapkan oleh Direktorat Jenderal Pengelolaan Utang atas nama Menteri. Penetapan hasil lelang SBSN sebagaimana dimaksud berupa menerima seluruh atau sebagian, atau menolak seluruh penawaran lelang SBSN yang masuk. Penetapan hasil lelang SBSN didasarkan atas pertimbangan antara lain harga, waktu pengajuan penawaran pembelian, volume, dan pengelolaan risiko utang.

Untuk kepentingan akuntabilits dan transparansi, dalam penerbitan dan penjualan SBSN secara lelang di pasar perdana dalam negeri diperlukan dokumentasi yang sekurang-kurangnya memuat hal-hal: pertama, dokumen transaksi Aset SBSN yang antara lain terdiri dari: (a) Perjanjian jual beli atau sewa menyewa Barang Milik Negara untuk digunakan sebagai Aset SBSN; (b) Perjanjian sewa menyewa Aset SBSN; (c) Perjanjian jual beli Aset SBSN, termasuk yang berupa objek pembiayaan SBSN; dan (d) Perjanjian penyertaan 
(partnership). Dokumen transaksi Aset SBSN sebagaimana disebutkan harus disesuaikan dengan akad SBSN yang diterbitkan.

Kedua, perjanjian perwaliamanatan yang diperlukan hanya dalam hal: (a) Apabila penerbitan SBSN dilakukan secara langsung oleh Pemerintah, maka perjanjian perwali amanatan ditandatangani oleh Direktur Jenderal Pengelolaan Utang dan Wali Amanat yang ditunjuk; (b) Apabila penerbitan SBSN dilakukan melalui Perusahaan Penerbit SBSN dan Perusahaan Penerbit SBSN menunjuk pihak lain untuk membantu melaksanakan fungsi Wali Amanat, maka perjanjian perwali amanatan ditandatangani oleh Direktur Jenderal Pengelolaan Utang, dewan direktur Perusahaan Penerbit SBSN dan pihak lain yang ditunjuk untuk membantu melaksanakan fungsi Wali Amanat. Ketiga, ketentuan dan syarat (terms and conditions) SBSN; dan keempat, fatwa atau pernyataan kesesuaian SBSN dengan prinsip syariah.

Kemudian apabila antara agen lelang SBSN dengan peserta lelang telah tercapai suatu kesepakatan, maka dibuat semacam setelmen, yaitu penyelesaian transaksi SBSN yang terdiri dari setelmen dana dan setelmen kepemilikan SBSN. Setelmen SBSN jangka panjang dilakukan paling lambat 5 (lima) hari kerja setelah tanggal pelaksanaan lelang $(\mathrm{T}+5)$. Sedangkan setelmen SBSN jangka pendek dilakukan paling lambat 2 (dua) hari kerja setelah tanggal pelaksanaan lelang $(\mathrm{T}+2)$. Jangka waktu SBSN dinyatakan dalam jumlah hari sebenarnya dan dihitung sejak 1 (satu) hari setelah tanggal Setelmen sampai dengan tanggal jatuh tempo. Jumlah hari (day count) untuk perhitungan imbalan berjalan (accrued return) menggunakan basis jumlah hari sebenarnya (actual per actual).

Perhitungan harga setelmen per unit SBSN dilakukan berdasarkan formula yang ditetapkan melalui peraturan menteri keuangan. Ruang lingkup pengertian harga setelmen terdiri dari: (a) harga yang dibayarkan atas lelang SBSN yang dimenangkan, sebesar harga bersih (clean price) atau imbal hasil yang telah dikonversi sebagai harga bersih yang diajukan dalam penawaran lelang SBSN dengan memperhitungkan imbalan berjalan (accrued return), dalam hal lelang SBSN dengan imbalan berupa kupon; atau (b) harga yang dibayarkan atas lelang SBSN yang dimenangkan, sebesar imbal hasil yang telah dikonversi sebagai harga bersih yang diajukan dalam penawaran lelang SBSN, dalam hal lelang SBSN dengan pembayaran imbalan secara diskonto (Pasal 1 angka 20). 
Berdasarkan Lampiran Peraturan Menteri Keuangan No. 11 /PMK. 08/2009 tentang Penerbitan dan Penjualan Surat Berharga Syariah Negara (SBSN) di Pasar Perdana Dalam Negeri dengan cara Lelang, diperoleh keterangan sebagai berikut:

(1) Cara Perhitungan Harga per unit SBSN.

$P_{K}=P+A_{R}$

\section{Keterangan:}

$P_{K}:$ Harga Setelmen per unit SBSN

$P$ : Harta Bersih (Clean Price) per unit SBSN

$A_{R}$ : Imbalan berjalan (Accrued Return) per unit SBSN.

Harta Bersih (Clean Price) per unit SBSN dihitung sebagai berukut:

$$
P=\left[\frac{N}{\left(1+\frac{i}{n}\right)^{\left[F-1+\frac{d}{E}\right]}}\right]+\left[\sum_{k=1}^{F} \frac{N \times \frac{c}{n}}{\left(1+\frac{i}{n}\right)\left(k-1+\frac{d}{E}\right)}\right]-\left(N \times \frac{c}{n} \times \frac{a}{E}\right)
$$

Imbalan berjalan (Accrued Return) per unit SBSN dihitung dengan formulasi sebagai berikut:

$$
A_{R}=N \times \frac{c}{n} \times \frac{a}{E}
$$

Keterangan:

$$
\begin{aligned}
& P \quad: \quad \text { Harga bersih (Clean Price) per unit SBSN } \\
& A_{R} \quad \text { : Imbalan berjalan (Accrued Return) per unit SBSN } \\
& N \text { : Nilai nominal SBSN } \\
& \text { a : Jumlah hari sebenarnya (actual days) yang dihitung sejak } 1 \\
& \text { c : Tingkat kupon/ imbalan } \\
& \text { d : Jumlah hari sebenarnya (actual days) yang dihitung sejak }
\end{aligned}
$$


persentase, sampai dengan 5 (lima) decimal, dengan kelipatan 0,03125 atau $1 / 32$.

$k \quad: \quad 1,2,3, \ldots \ldots \ldots \ldots, \mathrm{F}$

$F \quad$ : Jumlah frekuensi pembayaran kupon yang tersisa dari tanggal setelmen sampai dengan tanggal jatuh tempo

$n$ : Frekuensi pembayaran imbalan dalam satu tahun.

Harga bersih (clean price) dan imbalan berjalan (Accrued Return) masing-masing dibulatkan ke dalam rupiah penuh, dengan ketentuan apabila di bawah dan sama dengan 50 (lima puluh) sen dibulatkan menjadi 0 (nol), sedangkan diatas 50 (lima puluh) sen dibulatkan menjadi Rp. 1 (satu rupiah) (Lihat: Lampiran I Peraturan Menteri Keuangan No. 11 /PMK. 08/2009 tentang Penerbitan dan Penjualan SBSN di Pasar Perdana Dalam Negeri dengan cara Lelang)

\section{Contoh Perhitungan Harga Setelmen SBSN}

Pada tanggal 19 Januari 2009, Pemerintah menerbitkan SBSN dengan nilai nominal per unit Rp.1.000.000,00 (satu juta rupiah) dan dengan imbalan sebesar 12,00\% (dua belas persen) per tahun. SBSN ini jatuh tempo pada tanggal 15 Januari dan 15 Juli setiap tahunnya. Jika yield to maturity yang disepakati sebesar 12,50000\% (dua belas koma lima nol persen) dan Setelmen dilakukan pada tanggal 21 Januari 2009, maka Harga Setelmen per unit SBSN dihitung dengan langkah-langkah sebagai berikut:

\begin{tabular}{|l|l|}
\hline$N$ & Rp. 1.000.000,00 (satu juta rupiah) \\
\hline$i$ & $12,50000 \%$ (dua belas koma lima nol persen) \\
\hline$c$ & $12,00 \%$ (dua belas persen) \\
\hline$a$ & $\begin{array}{l}\text { 6 (enam) hari, yaitu jumlah hari sebenarnya (actual days) yang } \\
\text { dihitung sejak 1 (satu) hari sesudah tanggal dimulainya } \\
\text { periode kupon (16 Januari 2009) sampai dengan tanggal } \\
\text { Setelmen (21 Januari 2009). }\end{array}$ \\
\hline$d$ & $\begin{array}{l}175 \text { (seratus tujuh puluh lima) hari, yaitu jumlah hari } \\
\text { sebenarnya (actual days) yang dihitung sejak 1 (satu) hari } \\
\text { sesudah tanggal Setelmen (22 Januari 2009) sampai dengan } \\
\text { tanggal pembayaran kupon berikutnya (15 Juli 2009). }\end{array}$ \\
\hline$E$ & $\begin{array}{l}\text { 181 (seratus delapan puluh satu) hari, yaitu jumlah hari } \\
\text { sebenarnya (actual days) yang dihitung sejak 1 (satu) hari }\end{array}$ \\
\hline
\end{tabular}




\begin{tabular}{|l|l|}
\hline & $\begin{array}{l}\text { sesudah tanggal dimulainya periode kupon sampai dengan } \\
\text { tanggal pembayaran kupon berikutnya, di mana pelaksanaan } \\
\text { Setelmen terjadi (16 Januari 2009) sampai dengan (15 Juli 2009). }\end{array}$ \\
\hline$n$ & $\begin{array}{l}2 \text { (dua) kali dalam satu tahun (semiannually), yaitu setiap } \\
\text { tanggal 15 Juli dan 15 Januari. }\end{array}$ \\
\hline$F$ & $\begin{array}{l}\text { 10 (sepuluh) kali, yaitu jumlah pembayaran kupon yang terjadi } \\
\text { dari tanggal Setelmen sampai dengan tanggal jatuh tempo (21 } \\
\text { Januari 2008) sampai dengan (15 Januari 2014). }\end{array}$ \\
\hline
\end{tabular}

Dengan demikian, harga bersih (clean price) per unit dihitung sebagai berikut:

$$
\begin{aligned}
& P=\left[\frac{R p 1.000 .000,00}{\left(1+\frac{12,50000 \%}{2}\right)^{\left[10-1+\frac{175}{181}\right]}}\right]+\left[\frac{R p 1.000 .000,00 x \frac{12,00 \%}{2}}{\left(1+\frac{12,50000 \%}{2}\right)^{\left.1-1+\frac{175}{181}\right]}}\right. \\
& \frac{R p 1.000 .000,00 \times \frac{12,00 \%}{2}}{\left(1+\frac{12,50000 \%}{2}\right)^{\left[2-1+\frac{175}{181}\right]}}+\frac{R p 1.000 .000,00 x \frac{12,00 \%}{2}}{\left(1+\frac{12,50000 \%}{2}\right)^{\left[3-1+\frac{175}{181}\right]}} \\
& \frac{R p 1.000 .000,00 \times \frac{12,00 \%}{2}}{\left(1+\frac{12,50000 \%}{2}\right)^{\left[4-1+\frac{175}{181}\right]}}+\frac{R p 1.000 .000,00 \times \frac{12,00 \%}{2}}{\left(1+\frac{12,50000 \%}{2}\right)^{\left[5-1+\frac{175}{181}\right]}} \\
& \frac{R p 1.000 .000,00 \times \frac{12,00 \%}{2}}{\left(1+\frac{12,50000 \%}{2}\right)^{\left[6-1+\frac{175}{181}\right]}}+\frac{R p 1.000 .000,00 \times \frac{12,00 \%}{2}}{\left(1+\frac{12,50000 \%}{2}\right)^{\left[-1+\frac{175}{181}\right]}} \\
& \frac{R p 1.000 .000,00 \times \frac{12,00 \%}{2}}{\left(1+\frac{12,50000 \%}{2}\right)^{\left[8-1+\frac{175}{181}\right]}}+\frac{R p 1.000 .000,00 \times \frac{12,00 \%}{2}}{\left(1+\frac{12,50000 \%}{2}\right)^{\left[9-1+\frac{175}{181}\right]}} \\
& \left.\frac{R p 1.000 .000,00 \times \frac{12,00 \%}{2}}{\left(1+\frac{12,50000 \%}{2}\right)^{\left[10-1+\frac{175}{181}\right]}}\right]-\left(R p 1.000 .000,00 \times \frac{12,00 \%}{2} \times \frac{6}{181}\right)
\end{aligned}
$$


$=$ Rp. 546.491,48 + Rp437.299,39-Rp1.988,95

$=$ Rp. 981.801,92

$\approx$ Rp. $981.802,00$

Jadi, harga bersih per unit SBSN setelah dibulatkan adalah Rp. 981.802,00 (Sembilan ratus delapan puluh satu ribu delapan ratus dua rupiah), di mana imbalan dibayar dimuka (accrued return) per unit dihitung sebagai berikut:

$$
\begin{aligned}
A_{R} & =R p 1.000 .000,00 \times \frac{12,00 \%}{2} \times \frac{6}{181} \\
& =\text { Rp. } 1.988,95 \\
& =\text { Rp. } 1.989,00
\end{aligned}
$$

Jadi, imbalan berjalan per unit SBSN setelah dibulatkan adalah Rp. 1.989,00 (seribu sembilan ratus delapan puluh sembilan rupiah).

Harga setelmen per unit dihitung sebagai berikut:

$P_{K} \quad=$ Rp. $981.802,00+R p 1.989,00$

$=\operatorname{Rp} .983 .791,00$

Jadi, harga setelmen per unit SBSN setelah dibulatkan adalah Rp. 983.791,00 (sembilan ratus delapan puluh tiga ribu tujuh ratus sembilan puluh satu rupiah).

(2) Perhitungan Setelmen SBSN jangka pendek dengan imbalan berupa Diskonto.

$$
P=\frac{N}{1+\left(i \frac{D}{365}\right)}
$$

Keterangan:

$P \quad$ : Harga bersih (Clean Price) per unit SBSN

$N \quad$ : Nilai nominal SBSN 
$D \quad$ : Jumlah hari sebenarnya (actual days) yang dihitung sejak 1 (satu) hari sesudah tanggal setelmen sampai dengan tanggal jatuh tempo.

I : Imbal hasil jatuh tempo SBSN (yield to maturity) dalam persentase, sampai dengan 5 (lima) desimal, dengan kelipatan 0,03125 atau $1 / 32$.

Harga bersih (clean price) dan Imbalan Berjalan (Accrued Return) masing-masing dibulatkan ke dalam rupiah penuh, dengan ketentuan apabila di bawah dan sama dengan 50 (lima puluh) sen dibulatkan menjadi 0 (nol), sedangkan diatas 50 (lima puluh) sen dibulatkan menjadi Rp. 1 (satu rupiah).

\section{Contoh Perhitungan Harga SBSN dengan diskonto}

Pada tanggal 19 Januari 2009, pemerintah menerbitkan SBSN dengan nilai nominal per unit Rp. 1.000.000,00 (satu juta rupiah). SBSN ini jatuh tempo pada tanggal 21 April 2009. Jika yield to maturity yang disepakati sebesar 12,0000\% (dua belas koma nol persen) dan setelmen dilakukan pada tanggal 21 Januari 2009, maka Harga Setelmen per unit SBSN dihitung dengan langkah-langkah sebagai berikut:

\begin{tabular}{|l|l|}
\hline$N$ & Rp. 1.000.000,00 (satu juta rupiah) \\
\hline$D$ & $\begin{array}{l}\text { 90 (sembilan puluh hari), yaitu jumlah hari sebenarnya (actual } \\
\text { days) yang dihitung sejak 1 (satu) hari sesudah tanggal } \\
\text { setelmen (22 Januari 2009) sampai dengan tanggal jatuh tempo } \\
\text { (21 April 2009). }\end{array}$ \\
\hline$i$ & $12,0000 \%$ (dua belas koma nol persen) \\
\hline
\end{tabular}

$$
\begin{aligned}
P \quad & =\frac{R p \cdot 1000000}{1+\left(12,00000 \% \frac{90}{365}\right)} \\
& =\text { Rp. } 971 \cdot 261,31 \\
& \approx \text { Rp. } 971 \cdot 261,00
\end{aligned}
$$

Dari perhitungan diketahui, bahwa harga setelmen per unit SBSN setelah dibulatkan adalah Rp. 971.261,00 (sembilan ratus tujuh puluh satu ribu dura ratus enam puluh satu rupiah). 
Terkait pembayaran harga, peserta lelang bertanggung jawab terhadap seluruh penawaran pembelian masing-masing yang dinyatakan menang pada tanggal setelmen. Peserta lelang yang penawaran pembeliannya telah diterima oleh pemerintah, dinyatakan batal jika tidak melunasi seluruh kewajibannya sampai dengan batas akhir tanggal setelmen atau saldo giro rupiah bank yang ditunjuk sebagai bank pembayar di Bank Indonesia tidak mencukupi untuk pelaksanaan peluasanan sampai dengan batas akhir tanggal setelmen. Terhadap setiap pembatalan transaksi lelang SBSN, peserta lelang dikenakan sanksi tidak boleh mengikuti lelang SBSN sebanyak 3 (tiga) kali berturut-turut. Ketentuan lebih lanjut mengenai teknis pelaksanaan Setelmen SBSN mengikuti ketentuan yang ditetapkan oleh Bank Indonesia.

\section{KESIMPULAN}

Dari uraian tersebut dapat disimpulkan, bahwa lelang (al-muzayadah) merupakan salah satu model penjualan SBSN (sukuk Negara) yang telah diterbitkan. Penjualan SBSN secara lelang memiliki dasar hukum yang kuat menurut tinjauan syari'at. Karena itu fatwa DSN-MUI yang terkait dengan penjualan SBSN secara lelang telah ditindaklanjuti pemerintah dalam bentuk peraturan yang berlaku secara formal, termasuk ketentuan teknis menghitung penjualan SBSN itu sendiri.

\section{DAFTAR RUJUKAN}

Al-Mushlih, Abdullah dan Ash-Shawi, Shalah. 2004. Fikih Ekonomi Keuangan Islam (Maa Laa Yasa'u al-Taajir Jahlahu). Jakarta: Darul Haq

Al-Jaziri, Abdurrahman, t.t., Al-Figh 'Ala al-Madzahib Al-Arba'ah. Juz II/257

Accounting and Auditing Organization For Islamic Financial Institutions (AAOIFI). 2010. AAOIFI Shari'a Standard No. 17 tentang Investment (http:/ / www.aaoifi.com (di-download tanggal 6 Agustus 2010)

Fatwa No. 69/DSN-MUI/VI/2008 Tentang Surat Berharga Syariah Negara. 
Fatwa No: 70/DSN-MUI/VI/2008 Tentang Metode Penerbitan Surat Berharga Negara

Fatwa No: 71/DSN-MUI/VI/2008 Tentang Sale And Lease Back

Fatwa No: 72/DSN-MUI/VI/2008 Tentang Surat Berharga Syariah Negara Ijarah Sale And Lease Back

Huda, Nurul dan Nasution, Mustafa Edwin. 2007. Investasi Pada Pasar Modal Syariah. Jakarta: Prenada Media

Karim, Adiwarman A. 2001. Ekonomi Islam: Suatu Kajian Ekonomi Makro. Jakarta: Karim Business Cosulting

Menteri Keuangan No. 11 /PMK. 08/2009 tentang Penerbitan dan Penjualan Surat Berharga Syariah Negara di Pasar Perdana Dalam Negeri dengan cara Lelang

Burhanuddin, S. 2010. Surat Berharga Syari'ah Negara [Sukuk Negara]. Yogyakarta: Ijtihad Ilmu

Undang-Undang No. 19 Tahun 2008 tentang Surat Berharga Syariah Negara.

Peraturan Pemerintah No. 56 Tahun 2008 tentang Perusahaan Penerbit Surat Berharga Negara

Peraturan Pemerintah No. 57 Tahun 2008 tentang Pendirian Perusahaan Penerbit SBSN

Peraturan Menteri Keuangan No. 4/PMK.08/2009 tentang Pengelolaan Aset Surat Berharga Syariah Negara yang berasal dari Barang Milik Negara 